\title{
Editorial: language testing in the Philippines
}

\author{
STERLING M PLATA
}

Correspondence:

sterling.plata@gmail.com

De La Salle University, Manila, Philippines
Assessment reform is one of the keys to educational reform. In the Philippines, assessment reform is part of the $\mathrm{K}$ to 12 reform agenda implemented in June of 2012. As in any other reform, teachers are pressured to implement the changes in standards and student evaluation. One way to help teachers is by providing research reports that look into actual classroom assessment tools and models. School leaders also need to see how other educational institutions are able to successfully align national and school reforms.

It is for this reason that this special issue brings together research reports that look into classroom-based assessment of writing and speaking as well as a report documenting the process of aligning standards and assessment in the school and department level.

The first article will be of interest to those who have a writing process and writing assessment research agenda. The report provides a holistic scoring guide, a pilot-tested writing background questionnaire, and an idea generation process survey. Dr. Gustilo, the author of this paper, also reports findings that will be useful to those who want to find out if topic familiarity affects writing performance and if writing process affects written product.

The second article, on the other hand, will be of interest to school leaders and education policymakers because it documents the process of aligning a school's vision, its expected learning outcomes for all students, and assessment. It also describes the process that a department followed to integrate the school's reform agenda in its English 1 syllabus.

The third article is relevant to those who are exploring the topic of oral communication assessment. It reports how students used rubrics to understand their teacher's expectations as well as how they used the scoring guide to assess their own performance. The fourth and final article, on the other hand, is relevant to those who are interested in the role of feedback. This article takes a different approach because it does not merely describe the comments given by language teachers, but it also compares the comments of language and non-language teachers.

I hope that will issue will increase the interest of researchers not only in the Philippines but also in Asia as a whole on assessment reform. The collaborative efforts of researchers will help teachers and educational institutions to increase their assessment literacy and eventually improve teaching and learning. Finally, I would like to 
thank Dr. Robert Kirkpatrick for this special issue as well as the peer reviewers who took much time and effort to ensure the quality of papers in this journal.

Dr. Sterling M. Plata

Guest Editor

Received: 4 March 2013 Accepted: 4 March 2013

Published: 2 April 2013

doi:10.1186/2229-0443-3-1

Cite this article as: PLATA: Editorial: Language Testing in the Philippines. Language Testing in Asia 2013 3:1.

Submit your manuscript to a SpringerOpen ${ }^{\circ}$ journal and benefit from:

- Convenient online submission

- Rigorous peer review

- Immediate publication on acceptance

- Open access: articles freely available online

- High visibility within the field

- Retaining the copyright to your article

Submit your next manuscript at $>$ springeropen.com 